\title{
Partition of India: The Gurdaspur Dispute
}

\author{
Shivam Sharma \\ UID:20MSM3049 \\ University Institute of Sciences, \\ Department of Mathematics, Chandigarh University, \\ Gharuan, Mohali, Punjab-140413, Indiashivam@geekcops.com
}

\begin{abstract}
The Partition of India was arguably one of the largest Two-way migration in human history. There are several sets of census data and other verified sources which strengthens the argument that the exchange of population since 1947 has caused immense harm to the integrity of the Indian Sub-continent which is beyond repair. The paper discusses a brief history and the sequence of events that lead to the allotment of three out of four tehsil's of Gurdaspur district to the Indian dominion despite having a majority Muslim population. The importance of Gurdaspur was remarkable for both the dominions and the contested area was earlier assumed to be allotted to Pakistan while a later amendment made it a part of India, which opened routes for a direct pathway to Kashmir. It also discusses the Radcliffe Commission that was appointed to demarcate the two new separate dominions, India, and Pakistan in just eight weeks.
\end{abstract}

\section{KEYWORDS}

Radcliffe Line, Gurdaspur, Pathankot Tehsil, Kashmir, India's Partition

\section{INTRODUCTION}

\subsection{Role of Partition Politics}

A turning point in the development of South Asia was the partition of India. The strategic withdrawal resulted in British India's bifurcation into two successor dominions. The development of the Indo-Pakistani border remains an aspect of partition history that is ignored, but crucial. Originally, the political outcomes associated with the Indo-Pak territorial dispute originated from the Radcliffe Line. The authenticity of which is still a matter of legal cross-checks. India and Pakistan's debatable allegations have sparked a tidal wave of violent 
commotion within the sector of modern international relations. It is possible to assign one of the underlying causes of the dispute to the conflicting political orientations of the two countries. It is regarded by Pakistan as an unfinished policy of the 1947 Partition Plan and a complicated question of selfdetermination, a concept that is also approved by resolutions of the United Nations Security Council.

India, on the other hand, classifies it strictly as its territorial concern. Interestingly, however, it had stern opposition from the partition politics of the Pakistani side. Pakistani diplomats continue to believe that the allocation of the Muslim majority district of Gurdaspur to East Punjab, which provided India with a strategic lifeline to Jammu and Kashmir, caused them a severe injustice. [1] The erroneous allocation of the Muslim majority district of Gurdaspur to the Indian Dominion contradicted the constitutional mandates of the Indian Independence Act, 1947 (hereinafter 'Act'). Geographically, through the Upper Bari Doab canal system, Gurdaspur was almost irretrievably connected with Amritsar. And Ferozepur was therefore equally essential for the canals of the Pakistan Sutlej Valley Project.

Therefore, if the Radcliffe Commission had given priority over the economic argument to the majority population argument, then it should have assigned Gurdaspur to West Punjab. It can thus be hypothesized that instead of keeping with the strict globally accepted legal requirements for framing the boundary award, a political compromise was cleverly made. In that light, the important question remains: was there some influence or persuasion on the Radcliffe Commission to frame the award in favour of India's greater strategic interest? The divergence of the Commission from Muslim and non-Muslim contiguity to an overwhelming focus on other variables simply leaves an array of important issues unanswered.

\subsection{Corridor for Jammu and Kashmir}

Discussing the important issues that are at stake, we can begin by exploring the legal dynamics of public international law, which restricted the friendly resolution of the violent conflict. The face of modern Indian history was transformed by the formidable sources of confrontation and reciprocal recrimination associated with the events of 1947. It will also be mentioned in the course of the article that military support for India's de facto claim to Kashmir was undoubtedly supported by the natural corridor created by Gurdaspur. 
There were about 564 Princely States in India that were autonomous in the post-independence scenario of State Reorganisation. During the late 1940s, the significance of Jammu and Kashmir to the newly formed dominions can be mainly attributed to its notable growth. Jammu and Kashmir's administrative policies were reinforced by their competent domestic governance, greatly reinforced by the British development projects. [2 \& 3]

The effective administrative reorganization encouraged the state's economic development on a large scale. The importance of Kashmir to Pakistan now depends primarily on two factors, namely the production of its hydroelectric power and the security of irrigation water supplies in Punjab and Sindh. Besides, for both nations, the strategic value of Kashmir was immense.

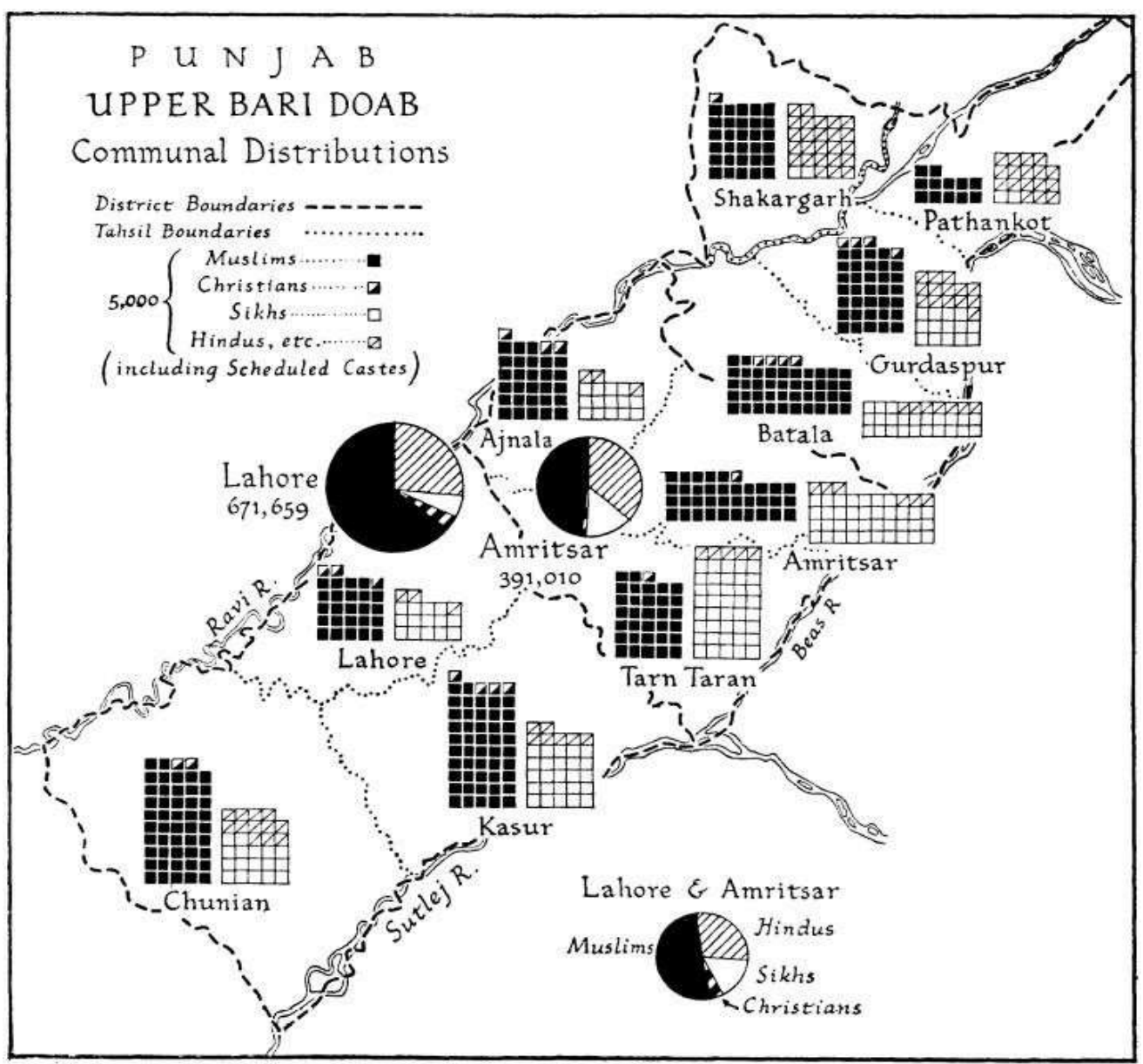

Figure 1: Boundaries of Tehsils and Districts, and visual representation of Pathankot serving as a direct pathway to Jammu and Kashmir. [4]

Some of the rivers of the Indus Basin, on which West Pakistan's canal system was focused, flowed out of Kashmir. Kashmir was not an isolated pocket; it was 
rather related to Western Punjab in geographical and historical terms. As a civilized and populated state, entire West Pakistan was dependent on the Indus and its tributaries for life. The Indus system's irrigation canals watered approximately 34 million acres of land in West Punjab at the time of partition. Of those, just five million acres were in eastern Punjab. It is important to note that for both dominions, Kashmir had tremendous strategic significance. As a student of history and international affairs, Nehru might imagine the value of the northwestern territory of India, where it shares a shared border with Afghanistan, a country with which India needs to have a special relationship. This is because entry to the former Soviet Union was provided by Afghanistan. They had also completely understood, along with Afghanistan, the strategic value of Kashmir, which had shared borders with both Afghanistan and China. Besides, he "virtually ensured that this critical land link with Kashmir remained in India," according to one of Nehru's biographers. It was, therefore, crucial for India to have a clear foothold over the north-western territories in deciding the goal. This will indirectly act as a bulwark for Pakistan's potential military gains in Kashmir. Professor Robert C. Mayfield argued that Pakistan would become so weak militarily without Kashmir that its western portion could never be effectively protected.

\section{DATA COLLECTION}

\subsection{Primary Sources}

Primary data are generated by a study explicitly designed to accommodate the needs of the problem at hand. Data were obtained through interviews and diaries.

\subsection{Secondary Sources}

The most common source of secondary data includes censuses, information collected by government departments, organizational records, and data that was originally collected for other research purposes.

\subsection{Data Analysis Method}

Data were evaluated and analysed through MS-Excel.

\subsection{Result Representation Techniques}

The data is represented through clustered column charts, and tables.

\section{DATA ANALYSIS}




\subsection{Pre-Partition: Religion Data of Gurdaspur}

4.1.1 Hindu \& Muslim Population data of Gurdaspur from 1901 to 1941.

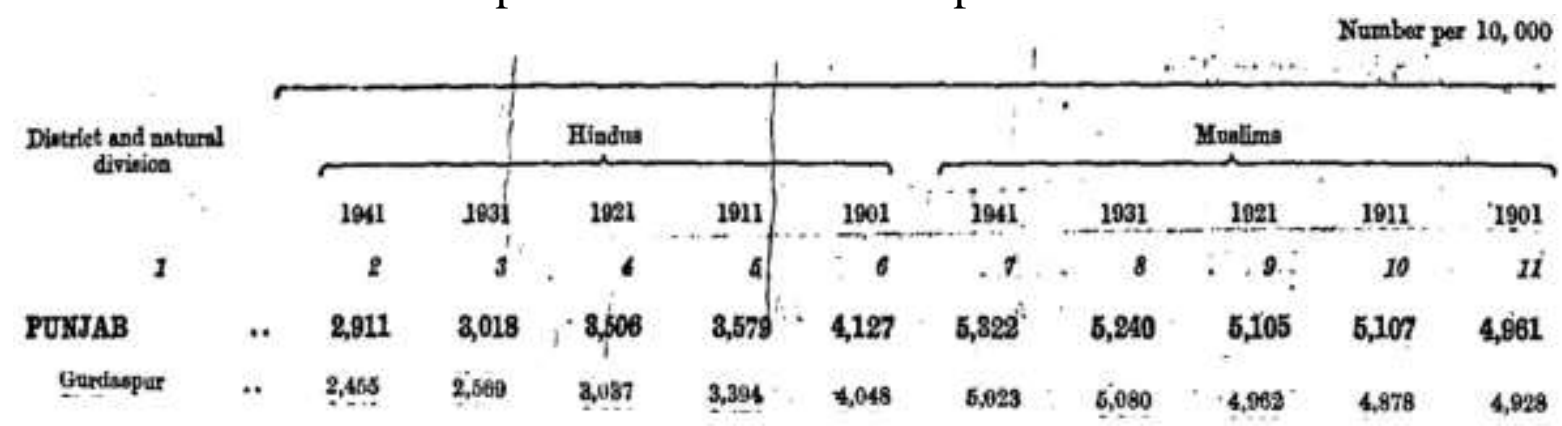

Figure 2: Census of India Vol VI, 1941 PUNJAB TABLES Pg. 48-49 [5]

CHART 1: Hindu-Muslim Census Data Pre-Partition: Per 10,000.

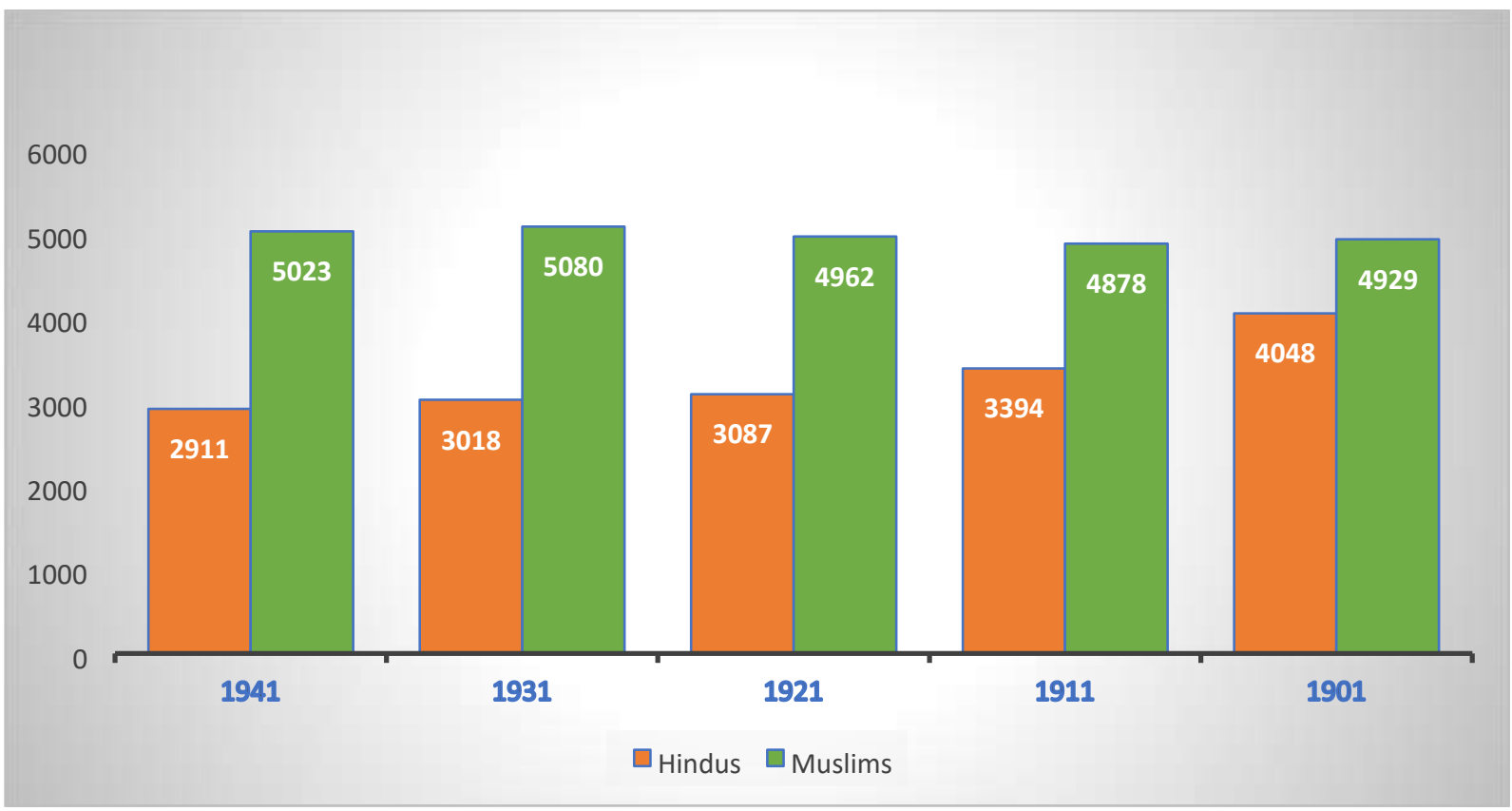

Hindu-Muslim: Census Data Pre-Partition

INTERPRETATION: The population of Hindus saw a sudden decline between 1901 and 1911 in the Gurdaspur district and continued to decline in number, whereas the establishment of the Muslim majority was evident since the beginning of 1901 and witnessed a rise by the end of 1941.[5]

4.1.2 Percentage of Sikh and Muslim Population data of Gurdaspur district and its constituent tehsils (Pre-Partition).

Table 1: Percentage of Sikh and Muslim Population in the tehsils in 1931 and 1941 [1] 


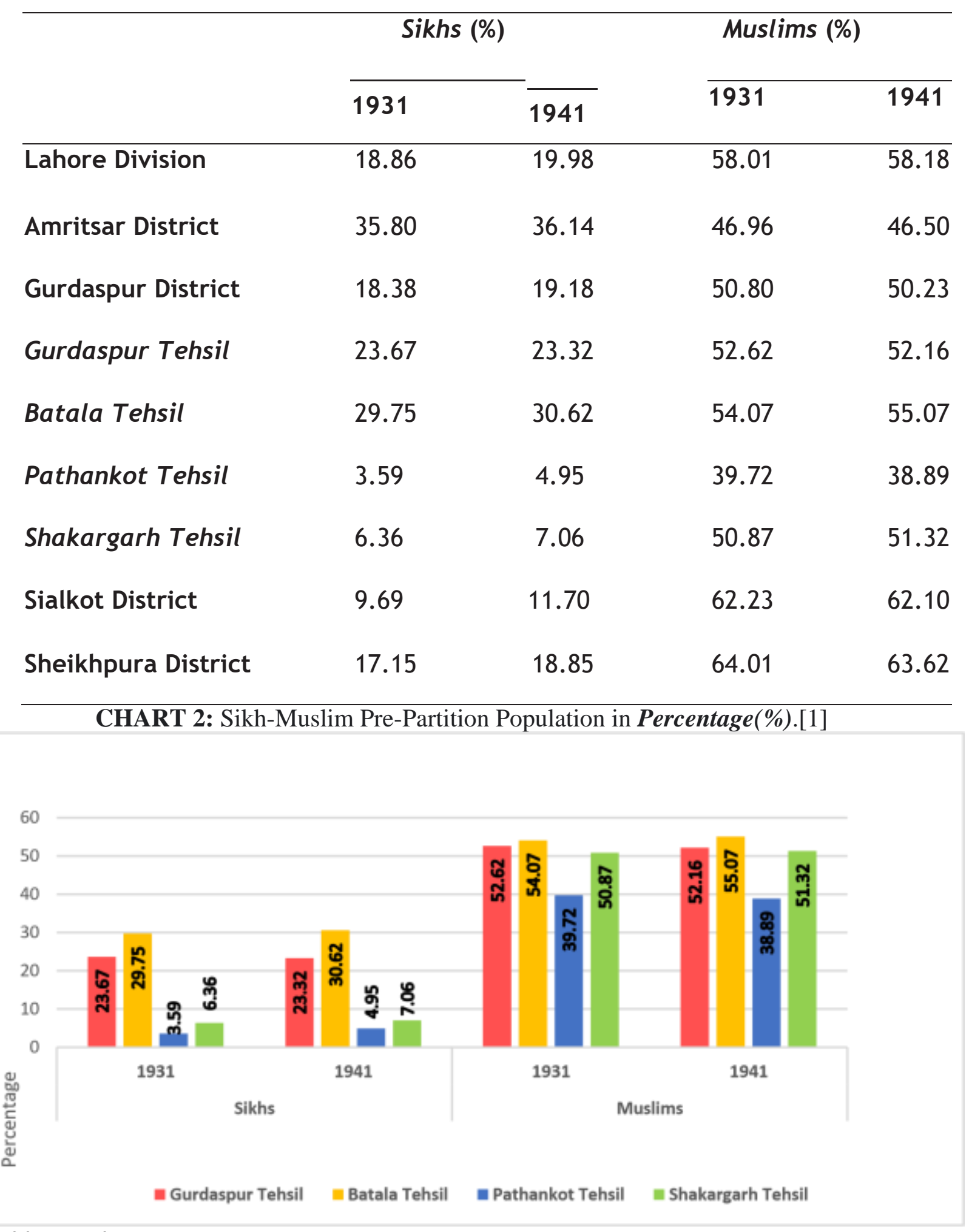

Sikh-Muslim: Census Data Pre-Partition

INTERPRETATION: The population of Muslims remained much higher than Sikhs in all the tehsils of the Gurdaspur district from 1931 to 1941.

\section{THE INCORRECT DISTRIBUTION IN VIOLATION OF THE LAW}


In the late 1940s, disturbances flared up in the provinces of Punjab and West Bengal, opposing the height of the partition politics of the British government. To bifurcate the land, the immense communal disturbances made it a dire necessity for a proper partition scheme. Concerning the conditions to be followed, during his address to the Chamber of Princes on 25 July 1947, Lord Mountbatten claimed that the partition would be carried out following the usual geographical situation and the interests of the nation. His $25^{\text {th }}$ July speech was somewhat different from what he had said at a press conference on $4^{\text {th }} \mathrm{June}$. He reported on $4^{\text {th }}$ June that the Boundary Commission is unlikely to throw the whole of the district of Gurdaspur into the Muslim majority areas. Nevertheless, a proposal was made to move the issue of border demarcation into the hands of the United Nations, but Nehru opposed the proposal on the ground that it would entail a lengthy process and an unnecessary delay.

Thus, under the chairmanship of Cyril Radcliffe, Lord Mountbatten created a Committee. The role of framing the Boundary Award was assigned to the Radcliffe Commission. The Commission's mixed constitution resulted in a deadlock and left it solely on Radcliffe to carry out all by himself a palpable partition line. This was largely a gross mistake because Radcliffe, a British barrister, had never visited India and was not aware of the country's thenprevalent socio-political scenario. Furthermore, the award was crafted in haste and without sufficient groundwork and background analysis, too.[1] Aaron Xavier Fellmeth noted that some of the convoluted and problematic Boundary Disputes escalated from colonial borders negotiated by the parties,' who were unaware of the African, Middle Eastern, or South American interior geography; and the boundary remains open to dispute in the absence of demarcation and precise delimitation.

\section{INFORMATION LEAKAGE AND EARLY CELEBRATIONS}

In the eyes of the constitution, the distribution of the Gurdaspur district to the Indian Dominion was evil. The constitutional mandates were followed according to the initial draft of the Award, but some fictitious developments within the period of 8-17 August 1947 inserted some changes into the Award, according to which India was granted three of the four Muslim-majority tehsils of Gurdaspur. Also, once Abell's letter to Abbott, which partially projects that the contents of the Award were leaked well before its actual publication, is examined, the ambiguities surrounding the Award will become apparent.

Besides, a hidden circle of the Viceroy's staff was also aware of the knowledge in advance. By August $10^{\text {th }}$, nearly all the data had been leaked to politicians. 
Chaudhry Muhammad Ali relates that he had visited Lord Ismay's office on $9^{\text {th }}$ August, where he inspected a map showing the outline of the proposed boundary in the form that the dominions eventually took. It can be safely assumed that this knowledge was passed on to Liaqat Ali by Chaudhri Muhammad Ali, that Gurdaspur with its bare Muslim majority would not be offered to Pakistan. Evidence indicates that just before the final announcement, Pakistan's flag was hoisted at Gurdaspur.

"For three days from August 14 ${ }^{\text {th }}, 1947$, there fluttered in Dalhousie's Gandhi Chowk, the flag of Pakistan, for it was rumored that Gurdaspur District (of which Dalhousie was a part) had been awarded to the new Muslim state. But on August $17^{\text {th }}$, the Tricolour took its place, forcing all the elite Muslim families that had gathered for their summer breaks in the hill station to migrate across the border in a single kafila."

\section{- Aanchal Malhotra (Historian) [6]}

It suggests that the Commission of Radcliffe did not work in full secrecy. Analysing all these events, it can be established that the results of the demarcation were announced well before it was finally written.

\section{CONCLUSION}

However, despite considerable discussion, the Radcliffe Award's descriptive historical accounts remain remarkably ambiguous and imprecise. By addressing some of the unanswered questions of historical importance, the paper has tried to crack the prolonged thoughts. For both dominions, the principle of bifurcation paved the way for uncountable practical problems. The Award exemplified the darker side of the partition strategy concealed underneath a socalled 'judicial process' as previously established. It left an irreplaceable mark on both nations' past and has stained their relationship since independence. While under the leadership of the Congress, the Indian political regime concentrated heavily on secularity and wanted equality in treatment, communal forces have always existed since the nation's inception. The above study has attempted to analyze the facts to see if Radcliffe's Partition Award has a more plausible explanation. One may admit at once that Pakistan is not favoured by the Radcliffe Award. The fact that the allocation of Gurdaspur was theoretically incorrect can be understood from a full-scale analysis of the economic and 
demographic build-up of undivided Punjab, its partition, and its potential legal basis.

\section{REFERENCES}

[1] SAURAV BHAUMIK "The Radcliffe Award Grant of Gurdaspur: An Elemental Key to the Indian Strategy in Kashmir" (History and Sociology of South Asia Part 1) (2015): 21-23.

[2] SYED RIFAAT HUSSAIN "Resolving the Kashmir Dispute: Blending Realism with Justice" (The Pakistan Development Review 48: 4 Part II) (2009): 1007-08.

[3] F.M. HASSNAIN "British Policy towards Kashmir (1846-1921)" (New Delhi: Sterling Publishers Pvt. Ltd.) (1945): 109-10.

[4] O. H. K. SPATE "The Partition of the Punjab and of Bengal" (The Geographical Journal, Vol. 110, No. 4/6) (1947): Figure 5, 207.

[5] Census of India, 1931, Vol. XVII (Lahore, Civil and Military Gazette Press) (1933), Part II, 'Tables' Table XVI, 'Religion', 278-79.

[6] AANCHAL MALHOTRA "How my book brought together two families, divided by Partition and united by a house" (Partition's Ghosts: Magazine Series Scroll.in) (2017) 